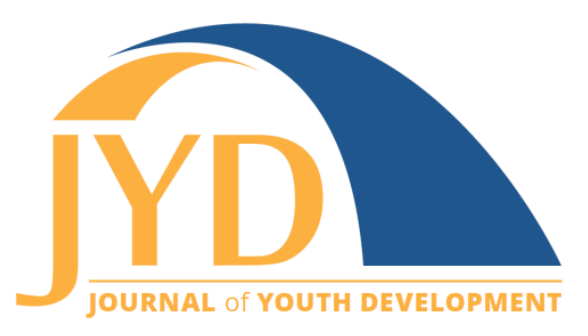

http://jyd. pitt. edu/ | Vol. 14 Issue 2 DOI 10.5195/jyd.2019.768 | ISSN 2325-4017 (online)

\title{
A Summer of Discovery at Filipino Cultural School
}

\section{Julia Noelani Javier Joo}

\begin{abstract}
Culturally specific youth development programs have a strong influence on the identity development of a number of youth from diverse cultural backgrounds. The following essay details a young person's experiences while attending a cultural school and provides important implications for youth development practitioners who serve youth from various cultural backgrounds and experiences.
\end{abstract}

Key words: Filipino, culture, school, immigrant

I am 11 years old and half-Filipino and half-Korean. A youth program that helped me learn about my unique Filipino immigrant family's heritage is Filipino Cultural School (FCS). Founded in 1965, FCS' mission is to increase education about Filipino culture to the community. I attended FCS during the summer on Saturdays. I learned a lot at FCS and made great memories. First, my most memorable moment was meeting my friends. I found they were also half Filipino like me! It was nice to know that there were other half Filipinos in the Filipino community because sometimes it's hard for me to feel like I fit in. Second, FCS' staff is amazing. I had three classes which were named Halo-Halo, Language, and Filipino martial arts (FMA). My teacher in Halo-Halo taught us about the different regions of the Philippines. My teacher in language taught us how to say words and sing a song in Tagalog. My teachers in FMA taught us about PaaMano Eskrima, a Filipino martial art that included sticks (but at first we practiced with pool noodles cut in half!).

During a typical day at FCS, the first thing I do is sign in. Then, I get my nametag. On the back of my nametag there is a stamp card. Each time I participate, do my homework, or have good behavior, the teacher or teachers give one or more stamps. Once you fill up two rows on your stamp card, you can shop at the sari-sari store where there are prizes. The sari-sari store at

(cc) $\mathbf{E Y}$ New articles in this journal are licensed under a Creative Commons Attribution 4.0 License. This journal is published by the University Library System, University of Pittsburgh and is cosponsored by the University of Pittsburgh Press. The Journal of Youth Development is the official peer-reviewed publication of the National Association of Extension 4-H Agents and the National AfterSchool Association. 


\section{Summer of Discovery at Filipino Cultural School}

FCS is modeled after a neighborhood variety store in the Philippines. If you fill up three rows, you can get two prizes. I think the sari-sari store is a fun way to "shop" in the Philippines. After signing in, I go to my first class called Halo-Halo. In this class I learn about different parts of the Philippines and how they live and what their different cultures are like. After the first class, I go to snack with my friends. After snack, I go to FMA class where I learn how to do martial arts 'Filipino style'. Then I go to lunch. After lunch, I go to my final class, language. In language I learn how to say words and phrases commonly used in the Philippines.

A day at FCS always ends with the "Family Games." Each student is placed in a family made up of children of different ages from 5 years old to 16 years old. I, for example, was placed in the family called Magandas (The beautiful mangos). At the Family Games, each family competes in a series of obstacles and challenges. Your goal is to win and earn points for your family. At the end of the FCS summer session, the family with the most points earns $25 \%$ off your registration next year. At the end of the summer, we have a graduation where we perform for the parents, showing them what we learned that summer. This year, my group sang "Bahay Kubo" and the Filipino national anthem and performed a Paamano Eskrima routine that we practiced in class. In FCS, I learned what it means to be a Filipino American. It means we are welcoming, diverse, and proud of our culture. 